\title{
The role of financial infrastructure in the regional reproduction process
}

\author{
AjdarAjupov $^{1, *}$, Diana Kurmanova ${ }^{2}$, Nailya Bagautdinova $^{1}$, and Liliya Kurmanova ${ }^{2}$ \\ ${ }^{1}$ Kazan Federal University, Institute of Management, Economics and Finance, 420008, Kazan, Russia \\ ${ }^{2}$ Bashkir State University, Ulitsa Zaki Validi, 32, Ufa, 450024, Russia
}

\begin{abstract}
The article considers modern conditions of financial support of reproductive processes. Due to the high concentration of financial market infrastructure in the central and "raw" regions of the country and the hypertrophied development of the financial sector, the timely and full implementation of regional programs for social and economic development is complicated, which indicates a high differentiation of regions in terms of financial provision and development of financial infrastructure. Clustering of the aggregate of the regions of the Russian Federation on the basis of selected economic indicators having a significant range of the coefficient of variation has been carried out, and the need for the development of the regional infrastructure of the financial market is substantiated.
\end{abstract}

\section{Introduction}

The financial system and financial and credit institutions provide an investment component of reproduction processes in economy. The creation of a stable, flexible and effective financial infrastructure is the most important objective for functioning of national economy and its regions that defines topicality of the conducted research. Increase in a share of the financial sector in the gross value added of the branches consuming financial services promotes effective redistribution of the financial capital and development of green economy. According to estimates of analysts, growth of capital investments by $1 \%$ provides increase in the produced gross internal product by $0,3-0,4 \%[1]$.

\section{Theory}

Imposition of economic sanctions concerning Russia became an essential barrier in attraction of average and long-term means by the Russian banks in the foreign capital markets. According to estimate of the Ministry of Finance of the Russian Federation, the short-received volume of the western capital is about USD 40 billion [2]. The volume of direct foreign investments is estimated by the Bank of Russia of 2,6 times lower than the 2013 level [3]. Today inflow of the capital to Russia in the form of portfolio and direct investments, deposits and credits doesn't even partly cover the requirement of the country for investment [4]. Available sources of loans became much more expensive. Rating

\footnotetext{
* Corresponding author: Ajdar.Ajupov@kpfu.ru
} 
downgrade of Russia, its regions and business by the leading international agencies up to "speculative" level with the adverse forecast was one more step of pressure [5]. Attraction of foreign investments is limited by external political and economic factors.

Search of internal sources of economic growth based on the development of a national financial system and its regional infrastructure is necessary in the conditions of external financing restriction. However, the activity of credit institutions in transformation of internal savings into investments with the smallest transaction expenses continues to remain low. Access to funding of the Bank of Russia is limited for regional credit organizations, despite expansion of a number of the banks allowed to participation in credit auctions. The sharpest shortage of "long-term money", especially in regions, for financing of investment projects and the high price of the credit for economic agents is observed [6]. The monetization coefficient characterizing the saturation of national economy by money in comparison with the main developed countries in the Russian Federation is the lowest 0,47 (tab. 1).

Table 1.Condition of monetary units, GDP and monetization coefficient of economy of the states [7].

\begin{tabular}{|l|l|l|l|}
\hline State & $\begin{array}{l}\text { Monetary aggregate M2 } \\
\text { (M3) as of 01/01/2014, in } \\
\text { billions of US dollars }\end{array}$ & $\begin{array}{l}\text { GDP for 2013, } \\
\text { billions of US } \\
\text { dollars }\end{array}$ & $\begin{array}{l}\text { Monetization } \\
\text { factor of the } \\
\text { economy (2/3) }\end{array}$ \\
\hline 1 & 2 & 3 & 4 \\
\hline Australia & 1357.4 & 1520.6 & 0.89 \\
\hline Great Britain & 3909.0 & 2440.0 & 1.6 \\
\hline Germany & 3172.3 & 3399.6 & 0.93 \\
\hline Canada & 1656.7 & 1821.4 & 0.91 \\
\hline China & 18785.0 & 8230.0 & 2.28 \\
\hline USA & 11011.6 & 15684.8 & 0.7 \\
\hline France & 2784.0 & 2612.9 & 1.06 \\
\hline Switzerland & 831.9 & 632.2 & 1.32 \\
\hline Japan & 11163.6 & 5960.0 & 1.87 \\
\hline Russian Federation & 947.3 & 2014.8 & 0.47 \\
\hline
\end{tabular}

According to Rosstat (Federal Service of State Statistics), in the financial sector of Russia in $20135 \%$ of GDP was produced. In the countries with the developed markets in the financial sector about $28 \%$ of GDP is produced [8]. At the regional level the share of financial activity in structure of gross value added of regions varies on federal districts from $1,0 \%$ (Central Federal District) up to $0,3 \%$ (other regions of Russia) that testifies about regional heterogeneity of investment space, high differentiation of regions on the level of financial security and development of a financial infrastructure, saving of an "export" model of national economy development. As a result, the main volume of capital investments is concentrated in export branches and raw regions. The modern period of functioning of the domestic financial market represents a transformational stage which isn't yet finished, and comprises a complex of the interactions connected with the "institutional lag" of economic development leading to restrictions of national economy growth, specific nature of the functioning mechanism of a market system in the country.

\section{Results}

Using a correlation and regression method based on the component analysis, the grouping of Russia regions on certain economic signs was made for an estimation of heterogeneity degree of regional territories in which economic processes are developed. Data of Federal State Statistics Service (Rosstat) was used as values of the basic economic indicators for 01.01.2013. 
Interrelations of resulting sign - the gross regional product (GRP) as key indicator of economic development (Y) and some factor signs, which can be used as financial security indicators of reproduction processes, were investigated. As factor indicators were selected the following variables: average monthly salary, rub (X1); the volume of contributions (deposits) of natural persons in Savings bank of the Russian Federation per capita, rub (on ruble and currency accounts) (X2); specific weight of the profitable organizations in the total number of the organizations, percent (X3); investments into fixed capital per capita, rub (X4); specific weight of population at working-age in the total number of the population, percent (X5); financial investments of the organizations, million rubles (X6). The component analysis of data was carried out by means of the STATGRAPHICS Plus 5.0 software product. For this purpose, we load the constructed selection into software product interface, then using the Principal Components function, we receive the following results (fig. 1).

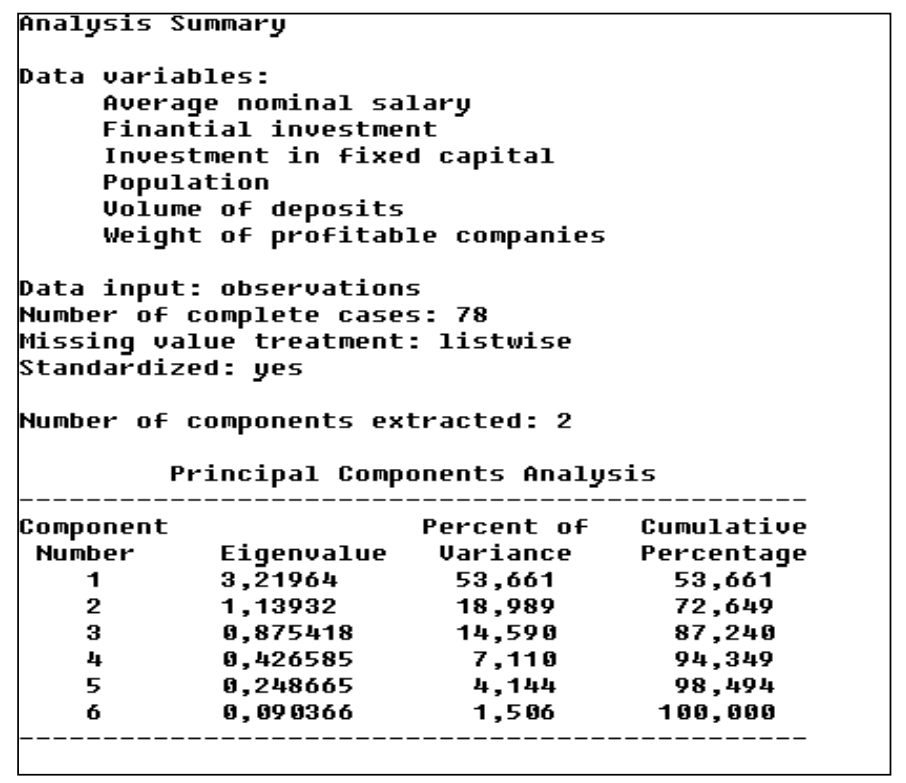

Fig. 1. Results of the first iteration of component of data analysis.

Obtained data demonstrate that already the first three components describe $87,24 \%$ of dispersion of initial data, the fourth component defines only $7 \%$ of the general dispersion of signs, and, therefore, it is inexpedient to include an additional component into studied model. On this step of a research, it is possible to define the most significant signs for carrying out the subsequent cluster analysis: X1, X3 and X6 since their specific weight on the module has the maximum value in all three components. Factors X2, X4 and X5 have small value of specific weight, and, therefore, within this research aren't significant. The data provided by results of the correlation analysis show the calculated values of main components. For example, for the first main components the equation of classification looks like the following: $0,454381 * \mathrm{X} 1+0,502995 * \mathrm{X} 6+0,525862 * \mathrm{X} 4+0,0340465 * \mathrm{X} 5+$ $0,460997^{*} \mathrm{X} 2+0,22433^{*} \mathrm{X} 3$, and values of variables in the equation are standardized. Further we will construct 2D - diagram for the set selection. In fig. 2 it is visible that the studied objects were grouped in three classes. 


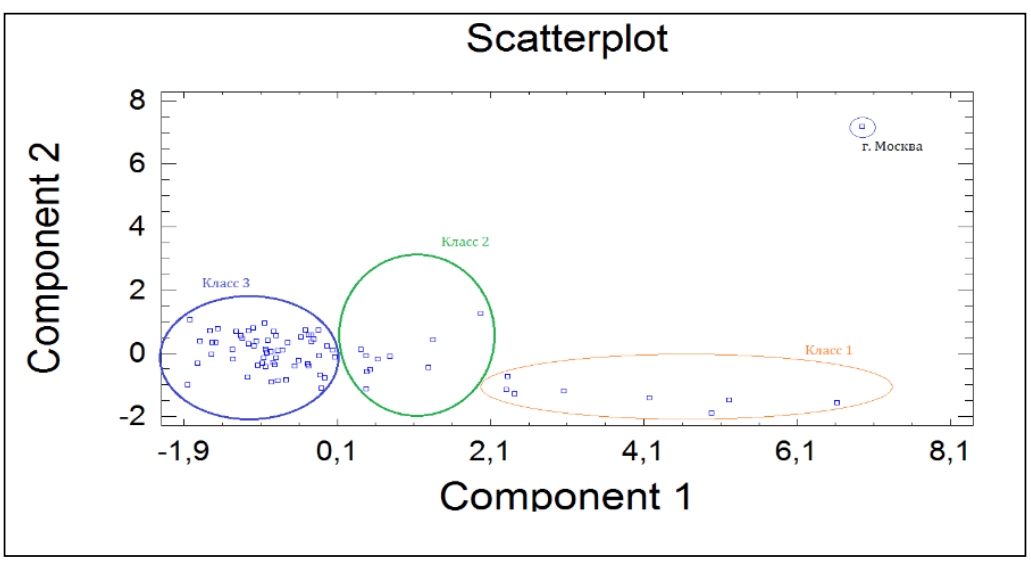

Fig. 2. Graphical representation of regions classification.

As a result, we define the objects belonging to classes. Moscow stands as separate "private house", doesn't belong to any class.

Table 2.Selected groups of regions based on the results of the iteration.

\begin{tabular}{|l|l|l|}
\hline Class 1 & Continuation- class 3 & Continuation- class 3 \\
\hline Chukotka Autonomous District & Samara Region & Saratov region \\
\hline Tyumen region & Kaluga region & Tambov Region \\
\hline Magadan Region & Republic of Bashkortostan & Oryol Oblast \\
\hline Sakhalin Oblast & Novgorod region & Penza region \\
\hline Kamchatka Krai & Krasnodar region & Chuvash Republic \\
\hline $\begin{array}{l}\text { The Republic of Sakha } \\
\text { (Yakutia) }\end{array}$ & Kemerovo Region & The Republic of Buryatia \\
\hline Komi Republic & Yaroslavl region & Mari El Republic \\
\hline Murmansk region & Nizhny Novgorod Region & Kurgan region \\
\hline & The Republic of Karelia & Bryansk region \\
\hline Class 2 & Lipetsk region & Pskov region \\
\hline St. Petersburg & Omsk Region & The Republic of Mordovia \\
\hline Moscow region & The Republic of Khakassia & Kirov region \\
\hline Khabarovsk region & Udmurt republic & Stavropol region \\
\hline Krasnoyarsk region & Jewish Autonomous Region & Altai region \\
\hline Arhangelsk region & Novosibirsk region & Republic of Adygea \\
\hline Tomsk Region & Voronezh region & Altai Republic \\
\hline Primorsky Krai & Chelyabinsk region & Ulyanovsk region \\
\hline Leningrad region & Kursk Region & Ivanovo region \\
\hline Amur region & Volgograd region & The Republic of Dagestan \\
\hline Kaliningrad region & Ryazan Oblast & $\begin{array}{l}\text { Karachay-Cherkess } \\
\text { Republic }\end{array}$ \\
\hline & & $\begin{array}{l}\text { Kabardino-Balkaria } \\
\text { Republic }\end{array}$ \\
\hline Class 3 & Astrakhan Region & Tyva Republic \\
\hline Republic of Tatarstan & Smolensk region & Republic of Kalmykia \\
\hline Belgorod region & Vologda Region & $\begin{array}{l}\text { The } \\
\text { Ingushetia }\end{array}$ \\
\hline Sverdlovsk region & Tula region & Chechen Republic \\
\hline Orenburg region & Vladimir region & Zabaykalsky Krai \\
\hline Irkutsk Oblast & Tver region & $\begin{array}{l}\text { Republic } \\
\text { Ossetia-Alania }\end{array}$ \\
\hline & Kostroma region & \\
\hline & Rostov region & \\
\hline & & \\
\hline
\end{tabular}


Regions of the Russian Federation are characterized by the strongest asymmetry on the level of economic development and influence of financial factors on economic processes. For confirmation of results we calculate coefficient of informational content (Kinf) which value gives the grounds to claim that the constructed model is reliable for $81,88 \%$ :

$$
K_{\text {inf }}=\frac{0.3136+0.64+0.5329}{0.3126+0.0626+0.1936+0.64+0.0729+0.5329}=0.8188
$$

Using the results of the carried-out analysis three groups of regions are selected on the basis of financial security factors of economic development which can be characterized as provided above an average (Class 1), average income (Class 2) and insufficiently provided (Class 3). Moscow didn't enter into one cluster, "leading region" is considerably torn off from the Class 1 that testifies that the level of use of financial factors in ensuring of reproduction processes in this region is highest.

The group of the regions carried to "Class 1" includes only $8 \%$ of total of regions, which differ in rather high level of financial security of regional development. Generally it is regions where considerable oil and gas income due to development of oil and gas branches of economy is formed. From here, ones have the high income of the population and savings capacity of the region, considerable financial investments (investment potential) and high specific weight of the profitable organizations (financial potential). In the 2 nd cluster are the regions with an average potential of development, their share makes $13 \%$.

Considerable part of subjects of Russia ( $78 \%$ of total of regions) are carried in the $3 \mathrm{rd}$ cluster, they insufficiently provided with financial resources, with the low level of development of the regional financial market and an insignificant set of financial instruments. In the third cluster regions differ among themselves in many parameters. The variation range on GRP per capita is 4,8 times (The Republic of Tatarstan 376889 rub and the Chechen Republic of 78934 rub), on the average monthly salary - 2 times (The Irkutsk region and the Republic of Dagestan accordingly to 25881 rub and $13660 \mathrm{rub}$ ), on the volume of deposits of the population - 8,2 times, on investments into fixed capital per capita $-6,6$ times. Calculation of statistical parameters of the Class 3 for the listed above indicators demonstrates that this group is non-uniform on the key economic indicators (Fig. 3).

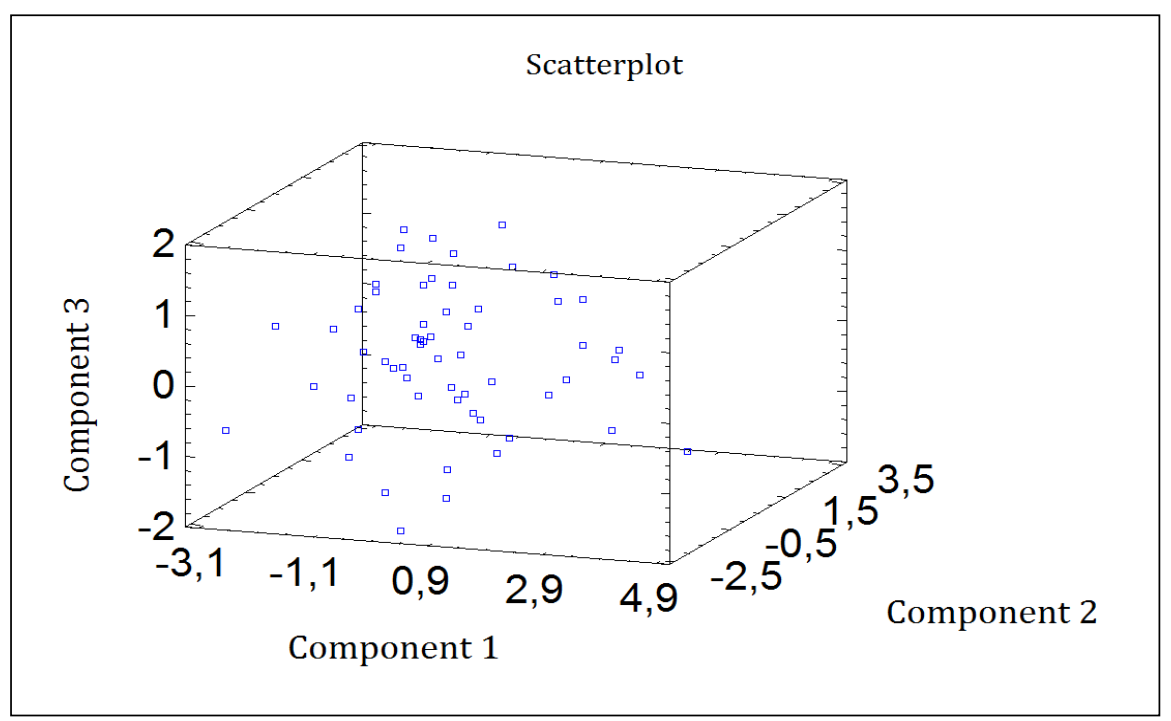


Fig. 3.Variation range of indicators of subjects of the Class 3.

The high gap in the third group, gave the grounds to carry out grouping inside cluster 3 and formation of subclusters that is visually presented in fig. 4.

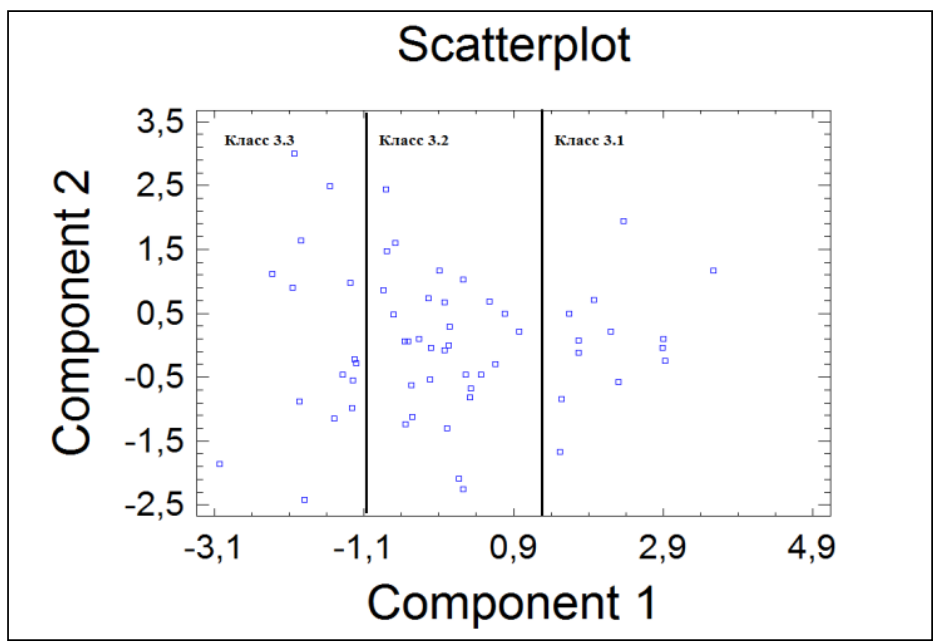

Fig. 4. Saturation of subjects on Class 3 subclasses.

Table 3.Grouping of subjects classified in Class 3 into subclasses.

\begin{tabular}{|l|l|l|}
\hline Class 3.1 & The Republic of Khakassia & Mari El Republic \\
\hline Republic of Tatarstan & Udmurt republic & Pskov region \\
\hline Belgorod region & Jewish Autonomous Region & The Republic of Mordovia \\
\hline Sverdlovsk region & Novosibirsk region & Kirov region \\
\hline Perm Region & Chelyabinsk region & Stavropol region \\
\hline Irkutsk region & Kursk Region & Altai region \\
\hline Samara Region & Volgograd region & Altai Republic \\
\hline Kaluga region & Ryazan Oblast & \\
\hline Republic of Bashkortostan & Astrakhan Region & Class 3.3 \\
\hline Novgorod region & Smolensk region & Kostroma region \\
\hline Kemerovo Region & Transbaikal region & Kurgan region \\
\hline Krasnodar region & Tula region & Bryansk region \\
\hline Nizhny Novgorod Region & Vladimir region & Republic of Adygea \\
\hline Voronezh region & Tver region & $\begin{array}{l}\text { Republic of North Ossetia- } \\
\text { Alania }\end{array}$ \\
\hline & Rostov region & Ivanovo region \\
\hline Class 3.2 & Ulyanovsk region & The Republic of Dagestan \\
\hline Orenburg region & Saratov region & $\begin{array}{l}\text { Karachay-Cherkess } \\
\text { Republic }\end{array}$ \\
\hline Vologda Region & Tambov Region & $\begin{array}{l}\text { Kabardino-Balkaria } \\
\text { Republic }\end{array}$ \\
\hline Yaroslavl region & Tyva Republic \\
\hline The Republic of Karelia & Penza region & Republic of Kalmykia \\
\hline Lipetsk region & Chuvash Republic & The Republic of Ingushetia \\
\hline Omsk Region & The Republic of Buryatia & Chechen Republic \\
\hline
\end{tabular}




\section{Conclusions}

Regional development of financial infrastructure has actual significant for the country with considerable territories in national borders and acts as a factor of financial safety, providing conditions not only redistributions on the basis of centralization, but also market accumulation in regions of sufficient financial resources.

The realized procedure of splitting non-uniform set of the Russian Federation regions on a number of economic signs indicates about growing interregional differentiation on the level of economic development, an essential gap between "economic poles" of the country, strengthening of social stratification and differentiation of standard of the population living. As a result of insufficiently developed financial infrastructure in regions "there is the strongest discrepancy between scale of the existing problems of regional social and economic policy and the financial resources allocated for their decision" [7].

Infrastructure development of regions becomes the defining factor and a condition of financial security of social and economic development of territories, providing interrelation of regional reproduction processes with nationwide. Security of regions with financial infrastructure is a basis of functioning of national economy as sets of its territorial branches therefore a criterion of infrastructure regional development of the financial market becomes important.

\section{References}

1. A. N. Melnik, O. N. Mustafina, Middle-East Journal of Scientific Research 13, 91-94 (2013)

2. J. B. Parr, The Regional Economy, Spatial Structure and Regional Urban Systems. Regional Studies (2013)

3. N. G. Bagautdinova, G.S.Tsvetkova, A.Z. Novenkova, World Applied Sciences Journal27(13), 58-61 (2013)

4. M. R. Safiullin, L. A. Elstin, A. I. Shakirova, Herald of the Russian Academy of Sciences4, 290-294 (2012)

5. L. N. Safiullin, G. N. Ismagilova, D. Kh. Gallyamova, N. Z. Safiullin, Procedia Economic and finance5, 667-676 (2013) DOI: 10.1016/S2212-5671(13)00078-6

6. A. A. Ajupov, A. A. Kurilova, R. S. Ozernov, Asian Social Science 11(11), 23-29 (2015)

7. A. A. Ajupov, A. A. Kurilova, D.U. Ivanov, Asian Social Science 11(11), 1-6 (2015)

8. A. A. Ajupov, A. A. Kurilova, K. Y. Kurilov, V. D. Bogatirev, Asian Social Science 11(11), 168-175 (2015)

9. A. A. Artamonova, A. A. Ajupov, Mediterranean Journal of Social Sciences 6(1S3), 24-29 (2015)

10. A. A. Ajupov, T. V. Polteva, Life Science Journal 11(6), 464-468 (2014)

11. A. A. Ajupov, O. E. Medvedeva, A. V. Freze, A. G. Savin, A. S. Karataev, Journal of Engineering and Applied Sciences 12(19), 4894-4898 (2017)

12. O. E. Medvedeva III International Research-to-Practice Conference "Modern Information Technologies and Innovations in Economy, State and Municipal Management and Social Sciences" (MITEC - 2018) (2018) 